\title{
Mapping and QTL analysis of the barley population Tallon $\times$ Kaputar
}

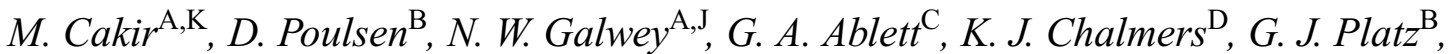

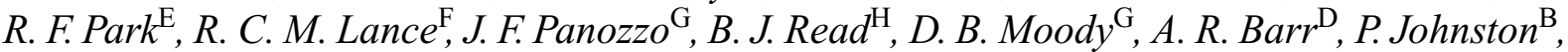

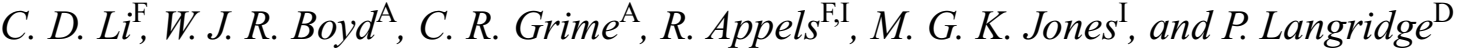

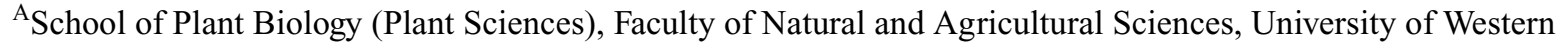 \\ Australia, Stirling Hwy, Crawley, WA 6907, Australia. \\ ${ }^{B}$ Queensland Department of Primary Industries, Hermitage Research Station, Warwick, Qld 4370, Australia. \\ ${ }^{\mathrm{C}}$ Centre for Plant Conservation Genetics, Southern Cross University, Lismore, NSW 2480, Australia. \\ ${ }^{\mathrm{D}}$ Department of Plant Science, University of Adelaide, Glen Osmond, SA 5064, Australia. \\ ${ }^{\mathrm{E}}$ University of Sydney, Plant Breeding Institute Cobbitty, Private Mail Bag 11, Camden, NSW 2570, Australia. \\ ${ }^{\mathrm{F}}$ Crop Improvement Institute, Department of Agriculture Western Australia, South Perth, WA 6151, Australia. \\ ${ }^{\mathrm{G}}$ Department of Primary Industries, Victorian Institute for Dryland Agriculture, Private Bag 260, Horsham, Vic \\ 3401, Australia. \\ ${ }^{\mathrm{H}}$ NSW Department of Agriculture, Wagga Wagga, NSW 2650, Australia. \\ IWA State Agricultural Biotechnology Centre, Murdoch University, Murdoch, WA 6150, Australia. \\ JPresent address: Oxagen Limited, 91 Milton Park, Abingdon, Oxfordshire, OX14 4RY England. \\ ${ }^{\mathrm{K}}$ Corresponding author; present address: WA State Agricultural Biotechnology Centre, Division of Science and \\ Engineering, Murdoch University, Murdoch, WA 6150, Australia; email: mcakir@murdoch.edu.au
}

\begin{abstract}
A genetic map of barley with 224 AFLP and 39 simple sequence repeat (SSR) markers was constructed using a doubled haploid (DH) mapping population from a cross between the varieties Tallon and Kaputar. Linkage groups were assigned to individual barley chromosomes using the published map locations of the SSR markers as reference points. This genetic map was used to identify markers with linkage to agronomic, disease, and quality traits in barley. The population, which comprised 65 lines, was tested in a range of environments across Australia. Quantitative trait loci (QTLs) analyses were performed using software packages MapMaker, MapManager, and Qgene. Significant associations with markers were found for several traits. Grain yield showed significant association with regions on chromosomes $2 \mathrm{H}, 3 \mathrm{H}$, and $5 \mathrm{H}$ over a range of sites throughout Australia. Regions on chromosomes $2 \mathrm{H}$ and $3 \mathrm{H}$ explained $30 \%$ and $26 \%$ of variation in lodging, respectively. Among quality traits, diastatic power was associated with regions on chromosomes $1 \mathrm{H}, 2 \mathrm{H}$, and $5 \mathrm{H}\left(R^{2}=37 \%\right)$. Hot water extract was associated with a region on chromosome $6 \mathrm{H}$ and a marker not assigned to a chromosome $\left(R^{2}=45 \%\right)$. There were also environment-specific QTLs for the traits analysed. The markers identified here present an opportunity for marker assisted selection of lines for these traits in barley breeding programs.
\end{abstract}

Additional keywords: SSR, AFLP, genetic mapping, quantitative trait loci.

\section{Introduction}

Genetic maps have been used to identify markers for single-gene and complex traits that are otherwise difficult and expensive to select for in plant breeding programs (Philips and Vasil 1999). Numerous studies have been conducted in barley to identify genetic markers for novel traits (Thomas et al. 1995; Kretschmer et al. 1997; Zhu et al. 1998; Marquez-Cedillo et al. 2000). The ultimate aim of these studies is to simultaneously improve the yield potential, quality characteristics, and disease traits of barley.

The National Barley Molecular Marker Program has focused on the quantitative trait locus (QTL) analysis of malting quality, agronomic, and disease resistance traits in a range of populations representing germplasm used across Australia.

This study presents the results obtained from genetic map construction and QTL analysis of agronomic, disease, and quality traits from the Tallon $\times$ Kaputar population.

\section{Materials and methods}

Plant material

The barley varieties Tallon and Kaputar were used to construct a doubled haploid (DH) population using the technique of anther culture. The population comprises 65 lines. Tallon (Triumph/Grimmett) is a 
Table 1. Pre-selective and selective primers, and their universal codes and sequences, used in the mapping of the Tallon $\times$ Kaputar population

\begin{tabular}{|c|c|c|}
\hline Primer & Universal code & Primer sequence \\
\hline \multicolumn{3}{|c|}{ Pre-selective primer } \\
\hline Pst I-A & $\mathrm{P} 01$ & 5'-GACTGCGTACATGCAG A-3' \\
\hline MseI-C & M02 & 5'-GATGAGTCCTGAGTAA C-3' \\
\hline \multicolumn{3}{|c|}{ Selective primer } \\
\hline$P s t \mathrm{I}-\mathrm{AA}$ & P11 & 5'-GACTGCGTACATGCAG AA-3' \\
\hline PstI-AC & $\mathrm{P} 12$ & 5'-GACTGCGTACATGCAG AC-3' \\
\hline PstI-AG & P13 & 5'-GACTGCGTACATGCAG AG-3' \\
\hline PstI-AT & $\mathrm{P} 14$ & 5'-GACTGCGTACATGCAG AT-3' \\
\hline MseI-CAA & M47 & 5'-GATGAGTCCTGAGTAA CAA-3' \\
\hline MseI-CAC & M48 & 5'-GATGAGTCCTGAGTAA CAC-3' \\
\hline MseI-CAG & M49 & 5'-GATGAGTCCTGAGTAA CAG-3' \\
\hline MseI-CAT & M50 & 5'-GATGAGTCCTGAGTAA CAT-3' \\
\hline MseI-CCT & M54 & 5'-GATGAGTCCTGAGTAA CCT-3' \\
\hline MseI-CGA & M55 & 5'-GATGAGTCCTGAGTAA CGA-3' \\
\hline MseI-CTG & M61 & 5'-GATGAGTCCTGAGTAA CTG-3' \\
\hline MseI-CTT & M62 & 5'-GATGAGTCCTGAGTAA CTT-3' \\
\hline
\end{tabular}

malting barley, bred in and adapted to the north-eastern region of Australia. Kaputar (5604/1025/3/Emir/Shabet//CM67/4 F 3 Bulk Hip) is a feed barley, bred by CIMMYT and released for the north-eastern region of Australia.

\section{Field trials and statistical analysis of phenotypic data}

Agronomic and yield trials of this population were conducted by barley breeding programs throughout Australia in 1998 and 1999. Quality traits were measured at VIDA (the Victorian Institute of Dryland Agriculture), Victoria, on samples taken from the 1998 harvest of trials at 5 locations (Warwick, Qld; Charlick, SA; Wagga Wagga, NSW; Wongan Hills and Katanning, WA). Assessment protocols were applied according to the Royal Australian Chemical Institute (2000). Numerous traits were scored, of which the following are reported here: yield, lodging, broken straw, basic vegetative period, maturity, Zadok value, net type net blotch, stripe rust, leaf rust, diastatic power, protein content, hot water extract, and $\alpha$-amylase activity.

Phenotypic data for every trait studied were collated and checked using GeNSTAT software (Genstat 5 Committee 1993). Statistical analysis was then performed (including spatial analysis and multi-environment analysis in some cases) to maximise the precision of estimating genetic effects.

\section{Molecular analysis}

\section{DNA extraction}

DNA was essentially carried out according to Rogowsky et al. (1991). Approximately $2 \mathrm{~g}$ of fresh leaf tissues from 10-day-old seedlings was ground in liquid nitrogen and incubated in $4 \mathrm{~mL}$ of Sarcosyl-based extraction buffer for $10 \mathrm{~min}$. A volume of $4 \mathrm{~mL}$ phenol-chloroform-isoamyl $(25: 24: 1)$ was added and then samples were homogenised for $10 \mathrm{~min}$ using a rotary centrifuge and then centrifuged for $10 \mathrm{~min}$ at $4000 \mathrm{rpm}$. After centrifugation, the aqueous phase was transferred to a clean $10-\mathrm{mL}$ tube and subjected to a second phenol-chloroform extraction, as above. The aqueous phase was transferred to a clean tube and $4 \mathrm{~mL}$ of cold isopropanol was added to precipitate the DNA. Tubes were inverted by hand $\sim 10$ times and precipitated DNA was either spooled out or spun down and afterwards washed with $70 \%$ warm EtOH. After air-drying the DNA pellet, $400 \mu \mathrm{L}$ of TE buffer containing RNAse $(40 \mu \mathrm{g} / \mathrm{mL})$ was added to each sample to resuspend the DNA overnight.

\section{AFLP analysis of genomic DNA}

Amplified fragment length polymorphism (AFLP) analysis was carried out essentially according to the procedure of Vos et al. (1995) with minor modifications. Adapters were as described by Vos et al. (1995). The list of pre-selective and selective primers used in this study is given in Table 1. Eight hundred nanograms of genomic DNA were double-digested with the restriction enzymes MseI and Pst I and ligated with the corresponding adapters. Total volume of the reaction was $60 \mu \mathrm{L}$ including $6 \mu \mathrm{L}$ of $10 \times$ restriction-ligation buffer $(100 \mathrm{~mm}$ TRIS-HCl, pH 7.5; $100 \mathrm{~mm}$ magnesium acetate; $500 \mathrm{~mm}$ potassium acetate; $50 \mathrm{mM}$ DDT), $1 \mu \mathrm{L}$ of each adaptor ( $5 \mu \mathrm{M}$ and $50 \mu \mathrm{M}$ for Pst I and MseI adaptor, respectively), $5 \mathrm{U}$ of each enzyme, $1.2 \mu \mathrm{L}$ of $10 \mathrm{~mm}$ ATP, and $0.2 \mu \mathrm{L}$ of T4 DNA ligase $(5 \mathrm{U} / \mu \mathrm{L})$. Samples were incubated at $37^{\circ} \mathrm{C}$ for $3 \mathrm{~h}$ using a PTC-100 Programmable Thermal Controller (MJ Research, Inc., Watertown, MA 02172, USA).

Pre-selective amplification reactions were performed in a $20-\mu \mathrm{L}$ volume, including $4 \mu \mathrm{L}$ of restricted-ligated template DNA, $1 \mu \mathrm{L}$ of each of the MseI-C and Pst I-A pre-selective primers ( $75 \mathrm{ng} / \mu \mathrm{L}$ each), $5 \mu \mathrm{L}$ of $5 \times$ polymerisation buffer (Fisher Biotech International, Perth, W. Aust.) containing $67 \mathrm{mM}$ TRIS- $\mathrm{HCl}(\mathrm{pH} 8.8), 16 \mathrm{~mm}\left[\mathrm{NH}_{4}\right]_{2} \mathrm{SO}_{4}$, $0.45 \%$ Triton X-100, $0.2 \mathrm{mg} / \mathrm{mL}$ of gelatin, $0.2 \mathrm{~mm}$ dNTPs, 1.2 units of Taq DNA polymerase, and $1.5 \mu \mathrm{L}$ of $\mathrm{MgCl}_{2}(25 \mathrm{mM})$. PCR amplifications were carried out in the thermocyler as mentioned above, with 20 cycles of $94^{\circ} \mathrm{C}$ for $30 \mathrm{~s}$ (denaturation), $56^{\circ} \mathrm{C}$ for $1 \mathrm{~min}$ (annealing), and $72^{\circ} \mathrm{C}$ for $1 \mathrm{~min}$ (extension). Pre-selective polymerase chain reaction (PCR) products were diluted 7 times and subjected to electrophoresis on $1.5 \%$ agarose gel for checking the amplification quality.

Selective amplification reactions were carried out in a $20-\mu \mathrm{L}$ reaction mixture containing $5 \mu \mathrm{L}$ of pre-selective product as template DNA, $4 \mu \mathrm{L}$ of $5 \times$ polymerisation buffer, $1.2 \mu \mathrm{L}$ of $\mathrm{MgCl}_{2}(25 \mathrm{~mm})$, $0.5 \mathrm{U}$ of $T a q$ DNA poplymerase, $0.15 \mu \mathrm{L}$ of fluorescent-labelled Pst $\mathrm{I}-\mathrm{XX}$ primer $(50 \mathrm{ng} / \mu \mathrm{L}), 0.45 \mu \mathrm{L}$ of unlabelled Pst $\mathrm{I}-\mathrm{XX}(50 \mathrm{ng} / \mu \mathrm{L})$, and $0.6 \mu \mathrm{L}$ of $M s e \mathrm{I}-\mathrm{XXX}$ primer $(50 \mathrm{ng} / \mu \mathrm{L})$. For this amplification, a 'touch-down' cycle profile was used as $94^{\circ} \mathrm{C}$ for $30 \mathrm{~s}, 65^{\circ} \mathrm{C}$ for $30 \mathrm{~s}$, and $72^{\circ} \mathrm{C}$ for $1 \mathrm{~min}$, reducing the annealing temperature by $1^{\circ} \mathrm{C}$ per cycle for 9 cycles to $56^{\circ} \mathrm{C}$. Once $56^{\circ} \mathrm{C}$ annealing temperature was reached, another 25 cycles were carried out to complete the selective amplification.

PstI selective primers were labelled with FAM, TET, and HEX fluorocolours. This allowed us to assay 3 Pst I selective primers for each 
MseI selective primer on the same gel by mixing $1 \mu \mathrm{L}$ from a reaction using each colour. The mixed PCR products were air-dried overnight at room temperature. The remainder of each PCR product was kept at $4{ }^{\circ} \mathrm{C}$.

\section{AFLP gel analysis}

AFLP marker products were separated by an ABI Prism 373 DNA sequencer (PE/Applied Biosystems) using 4.5\% polyacrlylamide gels containing $40 \mathrm{~g}$ urea, $9.5 \mathrm{~mL} \mathrm{40 \%} 19: 1$ acrylamide/bis, and $20.5 \mathrm{~mL}$ $\mathrm{dH}_{2} \mathrm{O}$. The urea was dissolved in warm water. One teaspoonful of resin was added to the urea solution and it was stirred for $5 \mathrm{~min}$. The solution

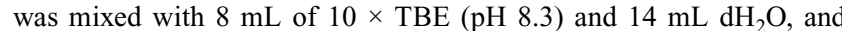
degassed for $10 \mathrm{~min}$. After adding and mixing thoroughly with the $400 \mu \mathrm{L}$ of $10 \%$ ammonium persulfate and $45 \mu \mathrm{L}$ TEMED, the gel solution was poured between glass plates and allowed to set for $2 \mathrm{~h}$. While the gels were setting, the air-dried PCR samples were resuspended with $2 \mu \mathrm{L}$ of loading buffer $(1.1 \mu \mathrm{L}$ formamide, $0.5 \mu \mathrm{L}$ loading dye, $0.4 \mu \mathrm{L}$ GeneScan 500 Tamra size marker). Following denaturation at $90^{\circ} \mathrm{C}$ for $3 \mathrm{~min}$, samples were immediately chilled on ice. Samples were loaded onto the gels at $1.8 \mu \mathrm{L}$ per lane.

GeneScan analysis software was used to analyse the AFLP markers. All marker loci were initially scored as $1 \mathrm{~s}$ and $0 \mathrm{~s}$, indicating presence and absence of the bands. These data were converted to mapping data as As and Bs representing the maternal and paternal genotypes, respectively. The KeyGene standard primer list was used to name the AFLP markers (Table 1), as published at the web address: http://wheat. pw.usda.gov/ggpages/keygeneAFLPs.html. Relative molecular weight and the initial of the contributing parent were also used in the naming of the markers. Marker names with initials of both parents represented co-dominant markers. Molecular weight information given with the co-dominant markers represented the parental band with lower molecular weight.

\section{SSR genotyping and analysis}

Simple sequence repeat (SSR) analysis was conducted by PCR amplification of the DNA with primers known to bracket SSR regions. Candidate SSR markers were selected from current published barley maps (Becker et al. 1995; Liu et al. 1996; Ramsay et al. 2000) based on their distribution along the barley chromosomes.

PCR was conducted in $10-\mu \mathrm{L}$ reaction samples, with $\mathrm{MgCl}_{2}$ optimised for each primer to between 1.5 and $3.0 \mathrm{mM} ; 200 \mu \mathrm{M}$ of each dNTP, 1× PCR buffer (Boehringer Mannheim), and 0.4 U Taq DNA polymerase. Genomic DNA was optimised for each batch of samples but was generally $20 \mathrm{ng}$ per sample. Thermal cycling conditions were as recommended with the publication of the primers $\left(94^{\circ} \mathrm{C}\right.$ for $3 \mathrm{~min}$ followed by $30-45$ cycles of: $94^{\circ} \mathrm{C}$ for $30 \mathrm{~s}$ or $1 \mathrm{~min} ; 45-58^{\circ} \mathrm{C}$ for $30 \mathrm{~s}$ or $1 \mathrm{~min}$; and $72^{\circ} \mathrm{C}$ for $30 \mathrm{~s}$ or $1 \mathrm{~min}$ ) (Ramsay et al. 2000) or by the touch-down method described above.

Either forwards or reverse primers were labelled with FAM, TET, or HEX ABI dyes. This allowed multiplexing of markers by colour and size on the same gel. Gel separation and detection of PCR products was performed on an ABI model 377 DNA sequencer or an ABI 310 Genetic Analyzer (capillary electrophoresis) using the internal standard GeneScan 500 (TAMRA). Genotyper 2.0 software (PE Applied Biosystems) was used for scoring of alleles.

\section{Statistical analysis of marker data}

SSR and AFLP marker data were collated for linkage analysis. All marker loci were subjected to a chi-square goodness-of-fit test for segregation analysis using Qgene software (Nelson 1997) to determine whether alleles were distributed in the $1: 1$ segregation ratio expected for a DH population. Linkage analysis of the markers was conducted using the software packages MapMaker/exp (Lander et al. 1987) and MapManager (Manly et al. 2001) using the Kosambi mapping function (Kosambi 1944). Linkages were established with a minimum LOD (logarithm of odds ratio) score of 3.0. LOD scores $<3.0$ were used to predict loose linkages in some instances. Map positions of the AFLP markers were established through linkage with the SSR markers, using the previously published map locations of the SSRs as a reference.

The genetic map was used to identify QTLs associated with the phenotypic data. QTL analyses were performed using MapManager QTX (Manly et al. 2001) and Qgene (Nelson 1997) software packages. A threshold LOD score of $2.5(P=0.001)$ was chosen for declaring the existence of a QTL. Regression and interval mapping analyses were used to identify marker associations with the traits. Single and multiple site analyses were performed for each trait.

\section{Results}

\section{Linkage map construction}

Two hundred and nineteen AFLP loci and 39 SSR loci were revealed as polymorphic between the parental lines. Sixteen out of the total of 279 polymorphic loci were found to have considerable distortion from the expected ratios and were excluded from the linkage analysis. Linkage groups were assigned to the 7 barley chromosomes, by reference to the location of the SSR markers (Fig. 1). These groups accounted for 177 loci. Small linkage groups that included 59 AFLP markers could not be assigned to any of the barley chromosomes in the absence of SSR markers. Twenty-seven loci could not be assigned to any of the linkage groups.

\section{QTL discovery}

About a third of the across-site variation in grain yield was found to be associated with regions on chromosomes $2 \mathrm{H}$ and $3 \mathrm{H}$. QTLs on $2 \mathrm{H}$ and $5 \mathrm{H}$ were associated with yield in 3 out of 5 environments. One QTL on each of chromosomes $2 \mathrm{H}$ and $3 \mathrm{H}$ was linked to lodging and broken straw traits (Table 2). Multiple regression analysis revealed that the same markers (p11m55K122 and p12m61TK118) from these regions had significant associations with lodging and broken straw, with total $R^{2}$ values of $42 \%$ and $40 \%$, respectively. QTLs on $2 \mathrm{H}, 3 \mathrm{H}, 6 \mathrm{H}, 7 \mathrm{H}$, and one marker not allocated to a linkage group explained $53 \%$ of the variation observed for basic vegetative period. Zadok score, a measurement of plant growth stage, appeared to be associated with QTLs on $2 \mathrm{H}$ and $3 \mathrm{H}$ in 2 environments. However, a location-specific QTL was also identified for Zadok score on chromosome $6 \mathrm{H}$ for the trial conducted at Blighty, NSW. The SSR marker EBmac0874 on $6 \mathrm{H}$ was linked to the maturity rating data collected from both Hermitage (Qld) and Toowoomba (Qld) (Table 2).

Several quality traits showed significant associations with marker loci. Based on the mean of data from all locations, both diastatic power and protein content were associated with regions on chromosomes $2 \mathrm{H}$ and $5 \mathrm{H}$. Location-specific QTLs for diastatic power were identified on chromosomes $6 \mathrm{H}$ and $7 \mathrm{H}$ for the data obtained from Charlick, SA, and Blighty, NSW, respectively. Hot water extract was associated with a region on chromosome $6 \mathrm{H}\left(R^{2}=30 \%\right)$ and a marker not yet assigned to a chromosome $\left(R^{2}=26 \%\right)$. Regions on 


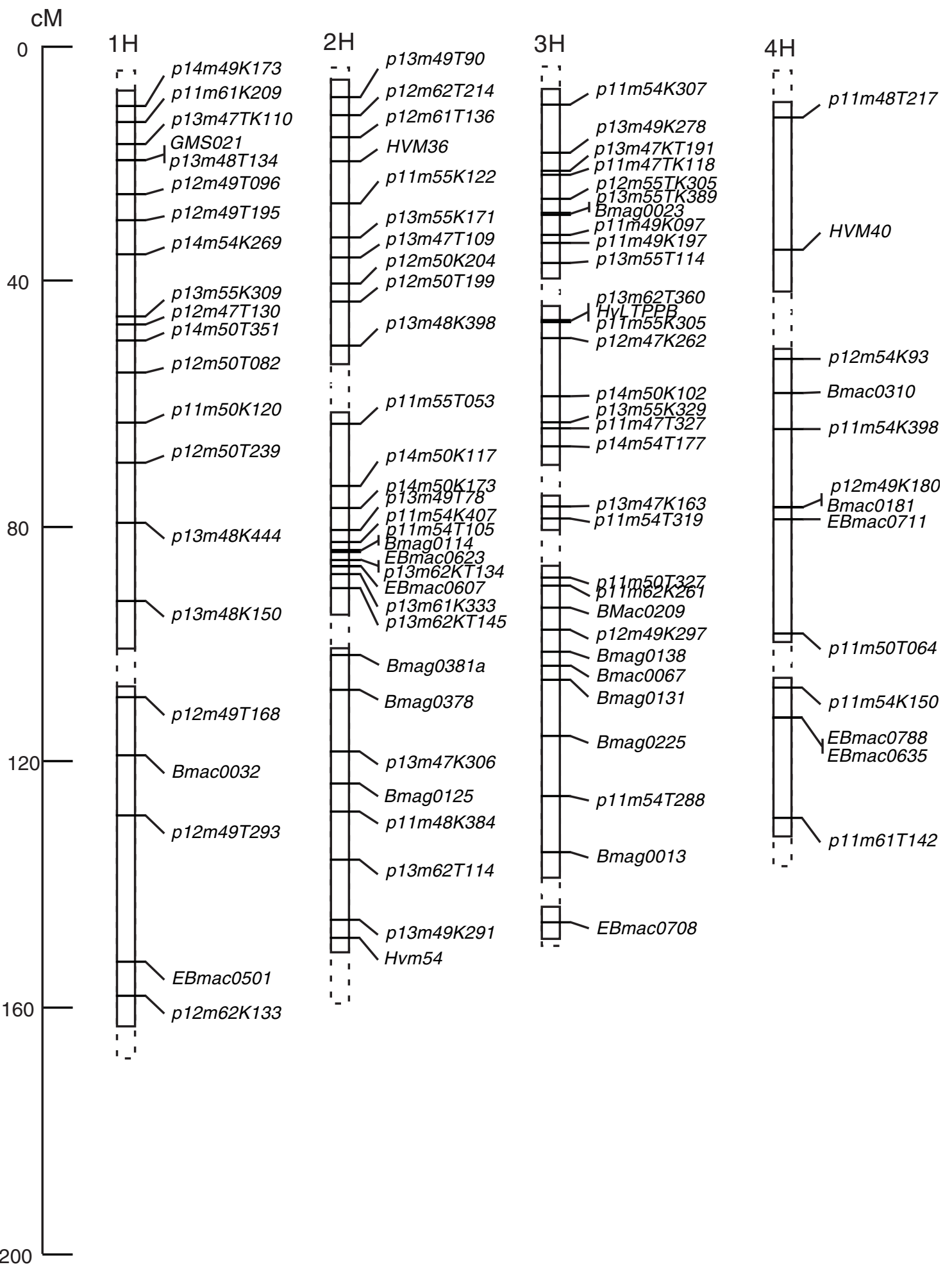

Fig. 1. Linkage map of barley chromosomes based on the Tallon $\times$ Kaputar mapping population. The scale in $\mathrm{cM}$ is shown on the left to indicate relative distances among the markers. Map distances were calculated with Kosambi function using software packages MapMaker and MapManager. AFLP markers were generated using PstI and MseI primer combinations (Table 1). Dashed lines were used to connect linkage blocks on chromosomes where linkages were less than a LOD score of 3.0. (Continued on next page.) 


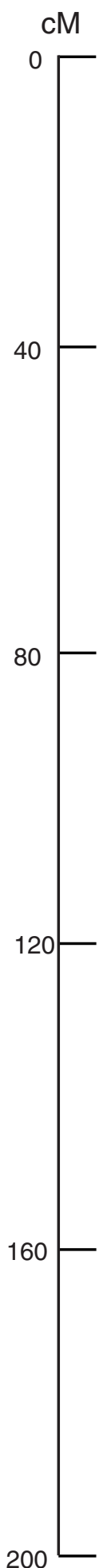

$5 \mathrm{H}$

. . p13m62K112

H p11m49T408

p $11 \mathrm{~m} 49 \mathrm{~K} 412$

p12m62k221

/EBmac0970 11 M $177 K 122$

Amag0387, Bmac0096

p13m54K358,p13m54T209

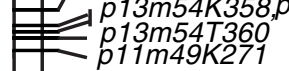

$\square$ p11m61k263

:

'́⿴囗十12m61K153

p12m54K226

p14m54K189

p13m62T055

p12m55TK114

- p11m54K140

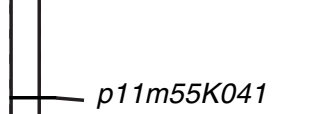

[ortm5skour

p12m55T063

p14m50K081

C p14m50K081

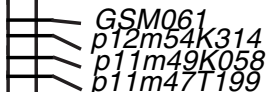

p11m47T199

p12m62T298

p11m61k233

р13m62T083

$\bigoplus_{-:}^{p 13 m 54 T 257}$
$6 \mathrm{H}$

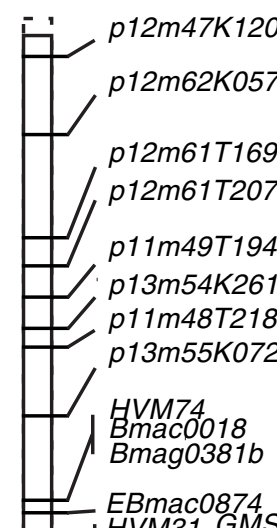

HVM31, GMS006

p12m61K116

Bmag0173

p11m54T416

p13m48T151
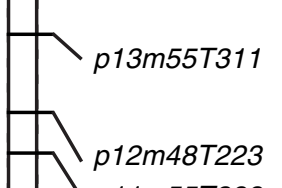

p11m55T388

$\longrightarrow$ p11m55KT185

p $13 m 54 K 083$

> p13m62K129

р 11 m50K088

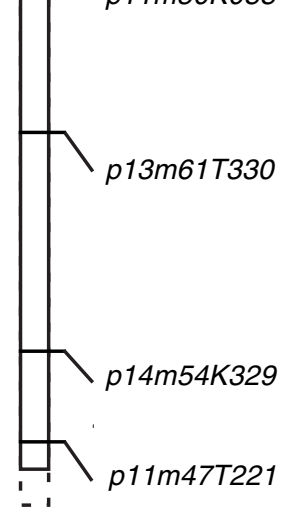

$7 \mathrm{H}$

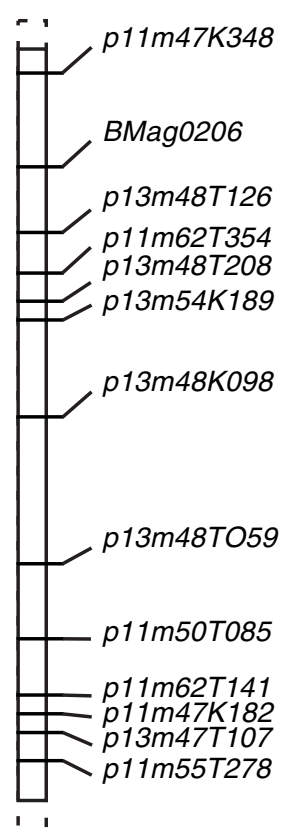

的 ${ }_{\text {Bmag0135 }}^{p 11 m 47 T 177}$

:

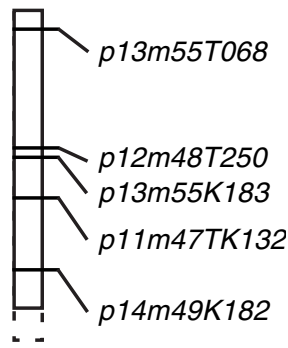

Fig. 1. (Continued). 
Table 2. Chromosomal locations and percentage variation accounted for by major QTLs for agronomic, disease, and quality traits in the barley doubled haploid population Tallon $\times$ Kaputar

\begin{tabular}{|c|c|c|c|c|c|}
\hline Trait & Location & Chrom. & $\begin{array}{l}\text { LOD }^{A} \\
\text { score }\end{array}$ & $\begin{array}{c}\% R^{2, \mathrm{~B}} \\
\text { variation }\end{array}$ & $\begin{array}{l}\text { Marker with } \\
\text { greatest effect }\end{array}$ \\
\hline \multirow[t]{4}{*}{ Grain yield } & \multirow[t]{4}{*}{ Mean of locations } & $2 \mathrm{H}$ & 2.95 & 20 & p13m61K333 \\
\hline & & $3 \mathrm{H}$ & 3.0 & 20 & p11m54K307 \\
\hline & & $5 \mathrm{H}$ & 2.60 & 18 & p13m54KT257 \\
\hline & & $5 \mathrm{H}$ & 1.95 & 12 & p11m49K271 \\
\hline Grain yield & Blighty, NSW & $5 \mathrm{H}$ & 3.15 & 21 & p13m54K058 \\
\hline \multirow[t]{2}{*}{ Grain yield } & \multirow[t]{2}{*}{ Charlick, SA } & $2 \mathrm{H}$ & 2.27 & 16 & p13m61K333 \\
\hline & & $5 \mathrm{H}$ & 3.38 & 23 & p14m50K081 \\
\hline \multirow[t]{2}{*}{ Grain yield } & \multirow[t]{2}{*}{ Katanning, WA } & $5 \mathrm{H}$ & 2.11 & 15 & p13m54T257 \\
\hline & & NA & 2.85 & 19 & p11m54T262 \\
\hline \multirow[t]{3}{*}{ Grain yield } & \multirow[t]{3}{*}{ Wongan Hills, WA } & $2 \mathrm{H}$ & 3.03 & 25 & p13m61K333 \\
\hline & & $3 \mathrm{H}$ & 4.06 & 29 & p11m54K307 \\
\hline & & $5 \mathrm{H}$ & 3.53 & 24 & p13m54T257 \\
\hline \multirow[t]{2}{*}{ Lodging } & \multirow[t]{2}{*}{ Wagga Wagga, NSW } & $2 \mathrm{H}$ & 4.68 & 30 & $\mathrm{p} 11 \mathrm{~m} 55 \mathrm{~K} 122$ \\
\hline & & $3 \mathrm{H}$ & 4.06 & 26 & p11m47TK118 \\
\hline \multirow[t]{2}{*}{ Broken straw } & \multirow[t]{2}{*}{ Wagga Wagga, NSW } & $2 \mathrm{H}$ & 4.86 & 31 & p11m55K122 \\
\hline & & $3 \mathrm{H}$ & 3.20 & 21 & p11m47TK118 \\
\hline \multirow[t]{3}{*}{ Basic vegetative period } & \multirow[t]{3}{*}{ Shenton Park, WA } & $2 \mathrm{H}$ & 3.98 & 28 & p13m47T109 \\
\hline & & $6 \mathrm{H}$ & 3.35 & 24 & p12m61T207 \\
\hline & & NA & 3.89 & 28 & p14m49K158 \\
\hline Maturity & Hermitage, Qld & $6 \mathrm{H}$ & 4.71 & 30 & EBmac0874 \\
\hline Maturity & Toowoomba, Qld & $6 \mathrm{H}$ & 6.6 & 40 & EBmac0874 \\
\hline \multirow[t]{2}{*}{ Zadok } & \multirow[t]{2}{*}{ Mean of locations } & $2 \mathrm{H}$ & 8.39 & 46 & p11m54T105 \\
\hline & & $3 \mathrm{H}$ & 6.50 & 38 & p11m47TK118 \\
\hline \multirow[t]{2}{*}{ Zadok } & \multirow[t]{2}{*}{ Hermitage, Qld } & $2 \mathrm{H}$ & 8.64 & 48 & p11m54T105 \\
\hline & & $3 \mathrm{H}$ & 4.86 & 30 & p11m47TK118 \\
\hline \multirow[t]{3}{*}{ Zadok } & Blighty, NSW & $2 \mathrm{H}$ & 5.49 & 39 & p11m54T105 \\
\hline & & $3 \mathrm{H}$ & 6.69 & 39 & p11m47TK118 \\
\hline & & $6 \mathrm{H}$ & 3.41 & 23 & Bmag0381 \\
\hline Net type net blotch (seedling) & Glasshouse & $2 \mathrm{H}$ & 4.58 & 29 & Bmag0114 \\
\hline & & $3 \mathrm{H}$ & 5.04 & 31 & p11m47TK118 \\
\hline & & $6 \mathrm{H}$ & 22.78 & 83 & Bmag0381 \\
\hline Net type net blotch ${ }^{\mathrm{C}}$ (adult plant) & Hermitage, Qld & $6 \mathrm{H}$ & 13.71 & 65 & EBmac0874 \\
\hline Stripe rust ${ }^{\mathrm{D}}$ (adult plant) & Toluca, Mexico & $2 \mathrm{H}$ & 6.02 & 36 & Bmag0114 \\
\hline & & $5 \mathrm{H}$ & 15.20 & 68 & $\mathrm{p} 12 \mathrm{~m} 54 \mathrm{~K} 314$ \\
\hline Leaf rust ${ }^{\mathrm{E}}$ (seedling) & Glasshouse & $2 \mathrm{H}$ & 2.4 & 16 & p14M50K117 \\
\hline & & $5 \mathrm{HS}$ & 1.8 & 10 & p12M54K226 \\
\hline & & $5 \mathrm{HL}$ & 3.1 & 21 & p12M54K314 \\
\hline Diastatic power & Mean of locations & $1 \mathrm{H}$ & 3.09 & 31 & p13m48K444 \\
\hline & & $2 \mathrm{H}$ & 2.84 & 28 & Bmag0114 \\
\hline & & $5 \mathrm{H}$ & 2.85 & 31 & $\mathrm{p} 12 \mathrm{~m} 54 \mathrm{~T} 257$ \\
\hline Diastatic power & Charlick, SA & $1 \mathrm{H}$ & 3.87 & 32 & p12m49T195 \\
\hline & & $2 \mathrm{H}$ & 2.00 & 18 & p14m50T209 \\
\hline & & $6 \mathrm{H}$ & 1.87 & 19 & p14m54K329 \\
\hline Diastatic power & Blighty, NSW & $1 \mathrm{H}$ & 5.43 & 37 & p12m49T195 \\
\hline Diastatic power & Wagga Wagga, NSW & $1 \mathrm{H}$ & 4.40 & 30 & p12m49T195 \\
\hline & & $5 \mathrm{H}$ & 2.62 & 19 & p12m54K226 \\
\hline Diastatic power & Katanning, WA & $2 \mathrm{H}$ & 4.46 & 40 & Bmag0114 \\
\hline & & $5 \mathrm{H}$ & 4.45 & 43 & $\mathrm{p} 12 \mathrm{~m} 54 \mathrm{~T} 257$ \\
\hline$\alpha$-Amylase activity & Mean of locations & $2 \mathrm{H}$ & 2.90 & 30 & p11m55K122 \\
\hline & & $7 \mathrm{H}$ & 2.08 & 22 & p11m50T085 \\
\hline Hot water extract & Mean of locations & $6 \mathrm{H}$ & 3.00 & 30 & p12m48T223 \\
\hline & & NA & 2.50 & 26 & p12m55T363 \\
\hline Protein content & Mean of locations & $2 \mathrm{H}$ & 4.31 & 40 & Bmag0114 \\
\hline & & $5 \mathrm{H}$ & 3.82 & 37 & p12m54K314 \\
\hline
\end{tabular}

\footnotetext{
${ }^{\text {A }}$ Logarithm of odds ratio.

${ }^{\mathrm{B}}$ Phenotypic variation explained by each marker.

${ }^{\mathrm{C}}$ For detailed discussion see Cakir et al. $(2003 a)$.

${ }^{D}$ For detailed discussion see Cakir et al. $(2003 b)$

${ }^{\mathrm{E}}$ For detailed discussion see Park et al. (2003).
} 
chromosomes $2 \mathrm{H}$ and $7 \mathrm{H}$ were associated with $\alpha$-amylase activity, with an $R^{2}$ of $30 \%$ and $20 \%$, respectively.

\section{Discussion}

This study has generated a set of precisely sized AFLP markers that could be used in comparative mapping of other populations - a process that allows quick and cost-effective mapping of traits in different genetic material. In conjunction with bulk segregant analysis we have applied this approach for detecting and validating QTL regions in other populations (Cakir et al. 2003a, this issue).

All of the SSR markers were mapped to their published locations (Ramsay et al. 2000), with the exception of Bmag0381. This SSR marker was mapped on both chromosome $2 \mathrm{H}$ and $6 \mathrm{H}$, in contrast to $2 \mathrm{H}$ only as reported by Ramsay et al. (2000). Possible reasons for this discrepancy are discussed elsewhere (Ablett et al. 2003, this issue).

Some of the AFLP markers were assigned to a specific chromosome based on their map locations in other genetic maps. This occurred in cases where the AFLP marker was not linked to any of the SSR markers. Previous research has shown that homologous AFLP fragments map on the same chromosomes in different populations (Waugh et al. 1997). The same conclusion was reached in our mapping of AFLP markers in different barley populations (data not shown).

Several significant QTL regions were identified from the Tallon $\times$ Kaputar population for different traits based on means of locations or years (Table 2). Loci were also identified that were associated with genotype $\times$ environment interaction for some of these traits. For example, principal component analysis of diastatic power identified a second component in which Katanning contrasted with the other sites studied (Charlick, Blighty, Wagga Wagga, and Wongan Hills). The expression of this component was associated with a region on chromosome $5 \mathrm{H}\left(R^{2}=43 \%\right)$. In other words, the data indicated that an allele could be selected in this region of the genome that would confer specific adaptation to environments similar to Katanning. A similar pattern was found for hot water extract (data not shown).

DNA markers are being used as tools in marker assisted selection of barley in breeding programs throughout Australia (Barr et al. 2000; Cakir et al. 2003c). Several markers that were associated with important traits have been identified in the mapping of the Tallon $\times$ Kaputar population and reported here and elsewhere in this issue (Cakir et al. 2003a, 2003b; Park et al. 2003). In addition, the use of SSR markers to assign AFLP linkage groups to the individual chromosomes of barley was demonstrated. The regions of the chromosomes in which significant markers were located in this study will be focal points of further research for validation and implementation of the markers for routine selection in breeding programs.

\section{Acknowledgments}

We thank Julie Uhlmann for her technical assistance in the laboratory. We are also grateful to the Western Australian State Agricultural Biotechnology Centre and Queensland Department of Primary Industries for providing laboratory facilities, and the Scottish Crop Research Institute for providing the SSR markers. Funding for this research is provided by GRDC through the National Barley Molecular Marker Program.

\section{References}

Ablett GA, Karakousis A, Banbury L, Cakir M, Holton TA, Langridge P, Henry RJ (2003) Application of SSR markers in the construction of Australian barley genetic maps. Australian Journal of Agricultural Research 54, 1187-1195.

Barr AR, Jefferies SP, Warner P, Moody DB, Chalmers KJ, Langridge $P$ (2000) Marker assisted selection in theory and practice. In 'Proceedings of 8th International Barley Genetics Symposium'. Vol. I, pp. 1167-178. (Dept of Plant Science, Adelaide University: Glen Osmond, S. Aust.)

Becker J, Vos P, Kuiper M, Salamini F, Heun M (1995) Combined mapping of AFLP and RFLP markers in barley. Molecular and General Genetics 249, 65-73.

Cakir M, Appels R, Carter M, Loughman R, Francki M, Li C, Johnson J, Bhave M, Wilson R, McLean R, Barclay I (2003c) Accelerated wheat breeding using molecular markers. In 'Proceedings of 10th International Wheat Genetics Symposium'. Vol. 1, pp. 117-120. (Istituto Sperimentale per la Cerealicoltura: Roma, Italy)

Cakir M, Gupta S, Platz GJ, Ablett GA, Loughman R, Emebiri LC, Poulsen D, Li CD, Lance RCM, Galwey NW, Jones MGK, Appels R (2003a) Mapping and validation of the genes for resistance to Pyrenophora teres f. teres in barley (Hordeum vulgare L.). Australian Journal of Agricultural Research 54, 1369-1377.

Cakir M, Spackman M, Wellings CR, Galwey NW, Moody DB, Poulsen D, Ogbonnaya FC, Vivar H (2003b) Molecular mapping as a tool for pre-emptive breeding for resistance to the exotic barley pathogen, Puccinia striiformis f. sp hordei. Australian Journal of Agricultural Research 54, 1351-1357.

Genstat 5 Committee (1993) 'Genstat 5 release 3 reference manual.' (Clarendon Press: Oxford, UK)

Kosambi DD (1944) The estimation of map distances from recombination values. Annals of Eugenics 12, 172-175.

Kretschmer JM, Chalmers KJ, Manning S, Karakousis A, Barr AR, Islam AKMR, Logue SJ, Choe YW, Barker SJ, Lance RCM, Langridge $\mathrm{P}$ (1997) RFLP mapping of the $\mathrm{HA}_{2}$ cereal cyst nematode resistance gene in barley. Theoretical and Applied Genetics 94, 1060-1064. doi:10.1007/S001220050515.

Lander ES, Green P, Abrahamsom J, Barlow A, Daly MJ, Lincoln SE, Newburg L (1987) MAPMAKER: an interactive computer package for constructing primary genetic linkage maps of experimental and natural populations. Genomics 1, 174-181.

Liu ZW, Biyashev RM, Maroof MA (1996) Development of simple sequence repeat DNA markers and their integration into a barley linkage map. Theoretical and Applied Genetics 93, 869-876.

Manly KF, Cudmore RH Jr, Meer JM (2001) Map Manager QTX, cross-platform software for genetic mapping. Mammalian Genome 12, 930-932. doi:10.1007/S00335-001-1016-3.

Marquez-Cedillo LA, Hayes PM, Jones BL, Kleinhofs A, Legge WG, Rossnagel BG, Sato K, Ullrich SE, Wessenberg DM, The North American Barley Genome Group (2000) QTL analysis of malting quality in barley based on the doubled haploid progeny of two elite 
North American varieties representing different germplasm groups. Theoretical and Applied Genetics 101, 173-184.

Nelson JC (1997) QGENE: software for marker-based genomic analysis and breeding. Molecular Breeding 3, 239-245. doi:10. 1023/A:1009604312050.

Park RF, Poulsen D, Barr AR, Cakir M, Moody DB, Raman H, Read BJ (2003) Mapping genes for resistance to Puccinia hordei in barley. Australian Journal of Agricultural Research 54, 1323-1333.

Philips RL, Vasil KI (1999) 'DNA-based markers in plants.' (Kluwer Academic Publishers: Dordrecht, The Netherlands).

Ramsay L, Macaulaya M, degli Ivanissevich S, MacLeana K, Cardlea L, Fullera J, Edwardsc KJ, Tuvessond S, Morganteb M, Massarie A, Maestrie E, Marmirolie N, Sjakstef T, Ganalg M, Powell W, Waugh $\mathrm{R}$ (2000) A simple sequence repeat-based linkage map of barley. Genetics 156, 1997-2005.

Rogowsky PM, Guidett FLY, Langridge P, Shepherd KW, Koebner RMD (1991) Isolation and characterization of wheat-rye recombinants involving chromosome arm 1DS of wheat. Theoretical and Applied Genetics 82, 537-544.

Royal Australian Chemical Institute (2000) 'Approved methods of the RACI Cereal Chemistry Division.' (RACI: North Melbourne, Vic.)
Thomas WTB, Powell W, Waugh R, Chalmers KJ, Barua UM, Jack P, Lea V, Forster BP, Swanston JS, Ellis RP, Hanson PR, Lance RCM (1995) Detection of quantitative trait loci for agronomic, yield, grain and disease characters in spring barley (Hordeum vulgare L.). Theoretical and Applied Genetics 91, 1037-1047.

Vos P, Hogers R, Bleeker M, Reijans M, Van De Lee T, Hornes M, Frijters A, Pot J, Peleman J, Kuiper M, Zabeau M (1995) AFLP: a new technique for DNA fingerprinting. Nucleic Acids Research 23, 4407-4414.

Waugh R, Bonar N, Baird E, Thomas B, Graner A, Hayes P, Powell W (1997) Homology of AFLP products in three mapping populations of barley. Molecular and General Genetics 255, 311-321. doi: $10.1007 / \mathrm{S} 004380050502$.

Zhu H, Briceno G, Dovel R, Hayes PM, Liu BH, Liu CT, Ullrich SE (1998) Molecular breeding for grain yield in barley: an evaluation of QTL effects in a spring barley cross. Theoretical and Applied Genetics 97, 774-779.

Manuscript received 12 December 2002, accepted 10 September 2003 